\title{
The year of daring: revisiting the Philippine left's dalliance with a strongman
}

Edition 6, 2021

Emerson M. Sanchez \& Dr Jayson S. Lamchek

DOI: 10.37839/MAR2652-550X6.13

It is perilous to be an activist in President Rodrigo Duterte's Philippines. The government's attacks on dissenters and activists have escalated in the name of counterterrorism over the past year, replicating the aggressiveness of its bloody and longstanding 'War on Drugs'.

During the period from June 2016 (when Duterte was inaugurated) to August 2020, 328 anti-government activists have been killed, according to human rights group Karapatan. The latest killings in this record were often carried out by unidentified perpetrators, suspected by Karapatan of being linked to state forces. The difficulty of identifying the perpetrators makes it challenging to claim justice for these killings. Over the past year, state security forces have become more brazen, in full view of the public, in raiding the offices of legal activist organisations. Many Manila-based activists have been falsely identified as communist rebels (a process known as 'redtagging'), and have been included on a terrorist list, which can have fatal consequences. In 2019, the Philippines was classified as the worst country in Asia for environmental defenders with 43 killings, according to Global Witness. Amid the COVID-19 pandemic, Duterte signed an anti-terror law that critics warn can allow most forms of political dissent to be sanctioned.

It is no surprise that the administration of Duterte, known for his anti-human rights 
rhetoric, would attack militant left activists associated with human rights groups. But this was not the case approximately five years ago.

From 2016 to 2017, the Duterte administration and the militant left movement established friendly relations in pursuit of progressive reforms and an end to decades-long armed conflict with communists. This sort of engagement between Philippine governments and progressive groups is not new and has been the subject of considerable scholarly attention. But the brief informal alliance between the Duterte administration and the militant left movement is important to examine because those involved are different from the past: the progressive group is more militant and the government has more authoritarian features.

After the downfall of the dictator Ferdinand Marcos Sr. in 1986, social democratic groups engaged with subsequent governments in an effort to transform politics. However, they largely ended up compromising heavily on government policies and becoming part of the electoral machineries of non-progressive politicians. Engagement with the Duterte administration, however, has involved a government espousing anti-human rights rhetoric and militant left groups that seek more radical socio-economic reforms.

Foremost among these groups are Bayan, a coalition of leftist organisations, and Makabayan, the leftist bloc in parliament. These two groups are organisationally distinct but ideologically aligned to underground groups such as the Communist Party of the Philippines (CPP), the New Peoples' Army (CPP's armed wing), and the National Democratic Front of the Philippines (CPP's political wing). Together they mobilised with the aim of transforming Philippine society into a 'national democracy', which is an extensive reform program based on revolutionary land reform and nationalised industries.

Contrary to the view that the left was subordinated to Duterte to give his 'fascist' rule a 'left gloss', we found that the left used a dual strategy vis-a-vis Duterte, or what we also call here a 'friend-and-foe' strategy. The left tried to maintain its 
cooperation with Duterte in hopes of advancing progressive policies and programs. At the same time, it opposed the Duterte administration's authoritarian tendencies, especially its anti-human rights rhetoric and actions.

In a recently published journal article, we explain the conditions for the emergence of the Duterte-left relationship, its challenges, and the tipping points that led to its collapse. We present a short version of the findings in this piece.

\section{Emergence of the left-Duterte relationship}

How was an alliance possible between Duterte and a left movement that saw itself as a radical democratising force, given Duterte's open endorsement of mass killings and anti-human rights rhetoric? Duterte's history of cooperation with the militant left and progressive elements of his campaign pronouncements were key.

Duterte had been successful in working with the militant left while he was Mayor of Davao City, despite his notoriety for supporting and fomenting drug-related extrajudicial killings. This working relationship resulted in progressive social programs in the city, such as a law on respect for women. Duterte also facilitated the release of high-level military captives of the CPP's New People's Army and is closely associated with Leoncio Evasco, a former communist rebel whom he recruited to be his chief of staff when he became Mayor. At university, Duterte was a student of CPP founder Jose Maria Sison, and became a member of the leftist youth organisation Kabataang Makabayan. Sison viewed these credentials as good reasons to believe that peace talks could be successfully pursued with the Philippine government should Duterte be elected.

Furthermore, some of Duterte's campaign promises aligned with the left's agenda, such as ending labour contracting, opposing environmentally destructive large-scale mining, and showing antipathy towards the country's alignment with the United States. Most importantly, Duterte promised to restart peace talks with both Moro separatists and communists engaged in armed conflict with the government, and to 
release political prisoners. Duterte's gestures towards the left became more convincing when he asked the CPP to nominate individuals to his Cabinet, resulting in the appointment of well-known militant left leaders, like peasant movement leader Rafael Mariano, former community organiser and professor Judy Taguiwalo, and former leftist party-list representative Liza Maza. These appointments were intended to jumpstart peace negotiations with the communists. Duterte also released CPP officials Benito and Wilma Tiamzon from detention.

\section{An explicitly anti-human rights rhetoric: the challenge for the left}

Because the left held itself out to be an advocate for human rights in the Philippines, particularly in the context of counterinsurgency, human rights issues tested the left's relationship with Duterte in a fundamental way. Leftists were pioneers of human rights work and built the first human rights organisations in the Philippines. Leftist human rights organisations were expected to speak out and act against the drugrelated killings. This expectation was heightened by the high-profile nature of much of their work, which sometimes seized national and international attention. Years of documentation by Karapatan and other groups, and transnational campaigning work that, at its peak, involved the United Nations Special Rapporteur Philip Alston, successfully shone a spotlight on the military campaign of extrajudicial killings of leftist activists and raised the stakes for the violators.

Because of the militant left's human rights work, it was expected to be a staunch critic of Duterte's 'War on Drugs' and to use its resources to help victims and their families. However, unlike the families of counterinsurgency victims who were more likely to be political and speak out, victims in the 'War on Drugs' came mainly from poor, apolitical families who were unlikely to make any sort of complaint. Compared to counterinsurgency killings, drug-related ones are of a different order of magnitude and documenting them would stretch any organisation's capabilities. These factors undoubtedly contributed to slowing down the response on the part of 
leftist human rights organisations. They did not, however, erase the basis for an oppositional position.

\section{Friend and foe: a dual strategy}

In the early days of the alliance, some observers noted that the left's appetite for critique, particularly its advocacy of human rights against the drug war, was dampened by appointments in the administration. It is true that the left took no interest in street protests in the early months of the Duterte administration and some leaders of the left initially defended Duterte from allegations of drug-related extrajudicial killings. Expressions of opposition to the War on Drugs nevertheless did emerge at the very beginning of Duterte's term. On July 1, 2016 the CPP supported the campaign against illegal drugs, but called for due process in anti-drug operations. However, by August 12, the CPP already condemned the drug war as 'anti-people' and 'undemocratic'.

Critics of the left, however, ask why militant left leaders remained in Duterte's Cabinet and as part of the legislature's pro-administration super-majority coalition until 2017. Prominent activist and academic, Walden Bello, argues that Duterte used peace talks with the communists as leverage to 'subordinate the militant left as a political force'.

We offer a different interpretation and argue that the left was both friend and foe, engaging in both contentious and cooperative actions to advance its own agenda. Its conduct reveals the contention aspect of the friend-and-foe relationship.

The left reciprocated Duterte's friendly gestures during the campaign with supportive pronouncements, and symbolically, by refraining from directing street protests against his government. Most conspicuously, on Duterte's first State of the Nation Address in July 2016, the left did not burn an effigy of the President as had been customary, and street rallyists proclaimed the rally was not 'antiadministration'. 
Notwithstanding the appointment of militant leaders in the Duterte Cabinet, Bayan Secretary General Renato Reyes stated that Bayan had not given up contention with the state: 'We are more than ever determined to arouse, organise and mobilise now given the favorable conditions'. He added that they would continue to fight policies and programmes believed to be unfavourable to the masses and continue their presence in the streets.

Militant left organisations opposed the continuation of neoliberal economic policies. The IBON Foundation, a think-tank close to the left, underlined the incongruence between Duterte's campaign pronouncements on labour contracting and national industrialisation and the actual policies pursued by his economic officials. The CPP and the National Democratic Front of the Philippines rejected neoliberal economic policies by proposing a Comprehensive Agreement on Socio-Economic Reforms through the peace talks with Duterte's government.

Some militant left groups also tested the possibilities and limits of the left/Duterte alliance. An example of this was Kadamay, the movement of informal settlers advocating for free mass housing for the poor. Kadamay's advocacy goes against the government's neoliberal approach to public housing through public-private partnerships. In March 2017, an informal group of settler families organised by Kadamay took over some 5,000 unoccupied public housing units in Pandi, Bulacan. Eventually, Duterte agreed to assign the unoccupied units to the occupying families, but in the same breath he vowed to repel further takeovers of empty assets by force, branding Kadamay's act 'anarchism'. The episode showed that Duterte meant to draw clear boundary lines for further collaboration with the militant left.

The pattern of pushing boundaries and being either rebuked or frustrated by lack of support from Duterte is discernible in other high-profile moves by militant left Cabinet members. As Secretary of Agrarian Reform, Rafael Mariano, urged Duterte to order a two-year moratorium on the conversion of land to non-agricultural uses, which was a device by which land was being removed from the scope of the land reform programme. 
Mariano's proposed moratorium had met with strong opposition from Duterte's economic team and Duterte eventually rejected the draft executive order to this effect. As Social Welfare and Development Secretary, Judy Taguiwalo had introduced changes to pre-existing welfare programmes meant to undercut their use in perpetuating patronage politics and corruption. These moves tended to disrupt the use of these funds for purely political purposes, and traditional politicians (known as trapos) quickly perceived them as such. Trapos often use their position to grant favours to others in exchange for political support. Duterte's lack of support ensured that in the ensuing conflict with trapos in the legislature over the confirmation of their appointments, the leftist Cabinet appointees were defenceless.

The presence of militant left leaders in government and in the pro-administration super-majority coalition in Congress could have given them access to resources and opportunities to push for reforms. But unlike social democrats in previous administrations who were rewarded with limited access to resources, attempts by the militant left at reform using their alliance with Duterte met with less hospitality from traditional politicians, big business, and the military. For example, they were unable to influence the conduct of the drug war. As for the peace talks, these too were subject to uncertainty. As Duterte increasingly pivoted towards a military approach to the revolutionary left, the militant left in government and Congress could only plead with him for more patience with the peace negotiations. The situation changed in November 2016.

\section{Tipping point: resuming radical opposition to authoritarianism}

The event that decisively broke the friend-and-foe relationship between the left and Duterte occurred on 18 November 2016, when the Marcos family, with Duterte's authorisation, buried their late patriarch, president-dictator Ferdinand Marcos, at the Heroes' Cemetery. Given the historical animosity between the left and the Marcos administration, the burial of Marcos in the Heroes' Cemetery was a 
contentious issue within the left-Duterte alliance. Bayan categorically opposed conferring 'any official honors for the dictator Marcos, whether as a hero, soldier, or former president'. Progressive groups attempted to block the burial, but it went ahead with the support of the Armed Forces of the Philippines. Bayan took an active role in the protests that afternoon.

On November 25, Bayan organised its first protest against Duterte, calling on the public to hold him accountable for the Marcos burial. Street protests by militant left groups prompted or allowed more radical expression of opposition over additional issues for the left-most notably, on December 10, Bayan and its allies organised a huge street protest for International Human Rights Day. Their demands included 'an end to impunity in the war on drugs, as the death toll rises and as state agents are emboldened by presidential pronouncements'.

The relationship between Duterte and the militant left worsened in the succeeding months. Drug-related killings continued to escalate. Progressive Cabinet members were not confirmed by the Commission of Appointments. The peace process become more uncertain. Militarisation of the countryside escalated as the administration attacked militant left activists, including human rights organisations. Finally, in September 2017, Makabayan broke away from Duterte's super-majority coalition. The militant lawmakers said they had initially supported Duterte for his progressive promises, but that the administration had unravelled into a 'fascist, pro-imperialist and anti-people regime', as Duterte halted the peace talks, declared martial law in Mindanao, and pursued a foreign policy dependent on China. 'Worst of all, his 'war on drugs' has turned into a campaign of mass murder of the poor', claimed Makabayan, with no indication of turning back.

\section{A full breakdown of the alliance}

It is an exaggeration to argue that Duterte simply subordinated the left as a political force. The left continued contentious actions against neoliberal economic policies 
and tested the boundaries of the alliance in attempts to actualise Duterte's promises of progressive reforms. But given the widening disparity between Duterte's promises and actions, the left's strategy of cooperation and contention could not last. The War on Drugs continues to result in the deaths in the tens of thousands and has defined the regime. The left may have been overly optimistic about Duterte's capacity to deliver on his promises on social and economic reforms. In light of Duterte's clear failure to deliver on reforms, it simply became untenable for the left to justify its high-level association with his government. The Marcos burial issue was the last straw.

Since the breakdown of the alliance, leftist human rights advocates have expanded their work to champion victims of the 'War on Drugs'. This is evident in their role in organising families of victims of drug-related killings, who, under the banner of 'Rise Up for Rights and for Life', filed a communication in August 2018 with the prosecutor of the International Criminal Court. Leftists are also instrumental in mobilising lawyers and paralegals who represent many of these families' demands for justice.

Taking a broader view of the history of progressive engagements with post-Marcos administrations, the failure of the left-Duterte alliance also underscores and confirms the extreme difficulty of pursuing reform of and within the Philippines' elite democracy. For the militant left, an alliance with Duterte represented a possible opportunity to achieve substantial concessions from elite classes through peace negotiations and high-level policymaking. In hindsight, its calculations may have been overly optimistic, having failed to take into account Duterte's own need for bases of power in the military and police as he battled other elite families and established himself as the nation's strongman.

As the Philippines lurches even more clearly towards authoritarianism, radical opposition, not progressive cooperation, is becoming more imperative.

Authors: Emerson M. Sanchez and Dr Jayson S. Lamchek 
Image: President Rodrigo Duterte in Seoul, 2018. Credit: Republic of Korea/Flickr. 